\title{
Impact of the Covid-19 Pandemic on Staffing Socio-Cultural Service and Tourism
}

\author{
A.V. Mitrofanova*, T.V. Kudryashova, V.A. Khilsher, L.V. Grosheva, V.Yu. \\ Nikolaicheva
}

Immanuel Kant Baltic Federal University, Kaliningrad, Russia

*Corresponding author. Email: mitrofanova-anna@mail.ru

\begin{abstract}
The article presents the results of a study of the impact of the COVID-19 pandemic on staffing in the sphere of social and cultural services and tourism, identifies the problem of a decrease in the quality of service for tourists due to the introduction of quarantine measures and the departure of qualified personnel from the profession, an analysis of educational programs and educational services for training personnel in the sphere of tourism presented in online and offline modes.
\end{abstract}

Keywords: hospitality industry personnel, domestic tourism, COVID-19, quality of service for tourists, educational and training programs.

\section{INTRODUCTION}

The COVID-19 pandemic has changed our lives, has had a serious impact on the development of all sectors of the economy, including the tourism sector. On the one hand, the introduction of quarantine measures, the suspension of the activities of enterprises in the hospitality industry led to an economic crisis, an increase in unemployment, on the other hand, the closure of the borders ensured the development of domestic tourism, the reorientation of tour operators working in the field of international tourism towards the formation and promotion of the domestic tourism market. During the period of quarantine measures, the activities of catering and accommodation establishments were suspended. This has led to reductions in tourism personnel and post-opening staff shortages.

\section{MATERIALS AND METHODS}

The methodological basis of the research is formed by general scientific methods, which include system analysis, synthesis and forecasting, comparison and statistical analysis.

Training of personnel in the field of tourism and hospitality is a systematic and organized training of qualified specialists in hotels and other accommodation facilities, facilities and means of recreation, public catering, as well as facilities for business, health, sports, and educational purposes.[2]. In connection with the growing demand for domestic tourism, the issue of training and advanced training of employees in the field of social and cultural services and tourism has become relevant. The quality of the services provided depends on the qualifications of the personnel, in connection with which the heads of the enterprises of the tourism industry are interested in hiring specialists with specialized education.

In the direction of training personnel in the field of social and cultural services and tourism in educational institutions, the following levels of training can be distinguished.

1. Higher professional education:

1.1. Master's degree [5]:

- Service;

-Tourism

-Hotel business.

1.2. Bachelor degree [5]:

- Service; 
-Tourism

-Hotel business.

2. Secondary special education [6]:

-Tourism

-Hotel service.

3. Additional professional education.

In the system of Additional professional education in accordance with The Federal Law of the Russian Federation "On Education" additional educational programs and additional educational services are implemented in order to fully meet the educational needs of citizens, society, state, industry. [8] At the moment, the standards of the new generation provide for the participation of employers' representatives in the development of educational programs, in the organization and implementation of the educational process, in assessing the quality of graduate training, and state certification. Such interaction effectively affects the level of future specialists training, contributes to their employment in the tourism sectors.

The total number of educational institutions that train personnel for the tourism industry in basic educational programs in the Russian Federation is more than 400. [1]

Table 1. Distribution of educational institutions that train personnel for the tourism industry by basic educational programs in the regions of the Russian Federation [1]

\begin{tabular}{|c|c|}
\hline Federal district & Number of educational organizations \\
\hline Central & 130 \\
\hline Northwestern & 49 \\
\hline Privolzhsky & 63 \\
\hline Southern & 40 \\
\hline Ural & 23 \\
\hline Siberian & 59 \\
\hline Far Eastern & 25 \\
\hline North Caucasian & 32 \\
\hline
\end{tabular}

The table does not include educational organizations specializing in additional educational programs. Currently, on the educational services market, especially during the COVID-19 pandemic lockdowns, a huge number of proposals have appeared in various fields of activity, including in the field of social and cultural services and tourism.

In addition to tourism training organizations, on-thejob training is of particular importance. Employers are interested in the high quality of services provided by their enterprise, therefore, they implement various forms of educational activities (trainings, master classes, business games, analysis of complex and conflict situations, training in enterprise standards in the form of lectures, mentoring, etc.).
The review of the existing levels of training in the field of tourism, educational programs, forms of educational activities implemented by educational organizations and managers of enterprises in the tourism industry is the scientific basis of this study and will allow us to assess the impact of the Covid-19 pandemic on staffing in the sphere of socio-cultural services and tourism.

\section{RESULTS AND DISCUSSION}

The period of the COVID-19 pandemic began in February 2020 and continues to the present. It is difficult to predict the development of the situation and develop business in such conditions. One of the first to be hit was the country's tourism sector. Closing borders, banning travel to other countries, reducing air travel and switching to distant work all affected tourism activities. After the resumption of the activities of enterprises in the hospitality industry, the Russian consumer, in connection with the closure of the borders, began to actively purchase tours in Russia. This was facilitated by the tool of cashbacks for traveling around the country launched by the Government of the Russian Federation. Due to the growing demand for domestic tourism, tour operators quickly reoriented themselves and began to form tourist products in different regions of the Russian Federation, representing different types of tourism.

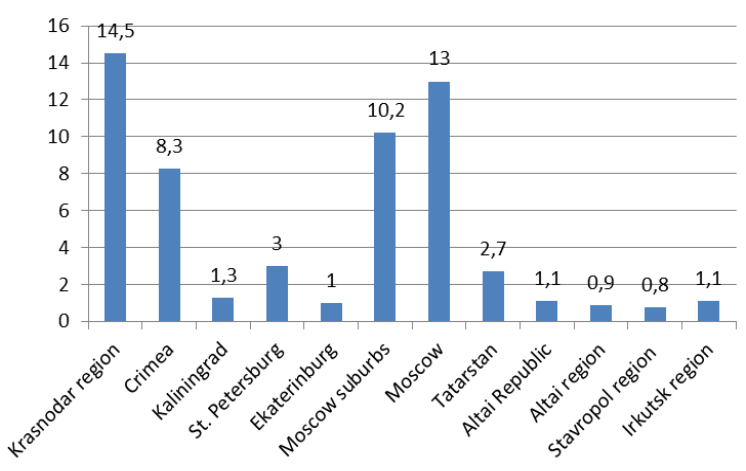

Figure 1. Domestic tourism statistics by regions of the Russian Federation for 8 months of 2021 (million people) [7]

However, the organizers of the tours are faced with the problem of the quality of the implementation of tourist services by intermediaries. In many regions, tourists noted the low level of training and customer focus of the hospitality personnel, the discrepancy between the declared level of service and reality.

This is due to the fact that personnel who have worked in the tourism sector for years were forced to leave the profession after the closure of the hospitality industry. Quarantine measures in the spring of 2020 showed that these enterprises are most dependent on the situation with the COVID-19 pandemic, trained personnel who have been working in the tourism industry for years have changed jobs. This situation led to the loss of the image of such professions as a waiter, 
bartender, hotel and restaurant manager, as well as others serving tourists. The economic crisis has led to a shortage of personnel, an acute shortage of professionals in both tourism and other sectors of the economy. After the launch of hospitality enterprises in the late spring of 2020, people who did not have the experience and the necessary qualifications came to replace the retired employees. This has led to a decline in the quality of the provision of tourist, hotel and restaurant services. This situation causes excitement both on the part of tour operators, owners of enterprises in the hospitality industry, and the Government of the Russian Federation and the regions.

According to the monthly report of a major Russian company, HeadHunter, the demand for job provision significantly exceeds the supply. Figure 2 shows the dynamics of these two components, where demand is the vacancies posted by employers who have been active in the aggregator for 30 days, and the offer is CVs created or updated by the applicants themselves over 60 days. From January to October 2021, one can observe a constant increase in the demand for job seekers, while the supply constantly varies from 0 to $16 \%$. At the moment, the offer has reached $13 \%$ and continues to grow to this day, while the offer for the second month stands at around 61\% [11].

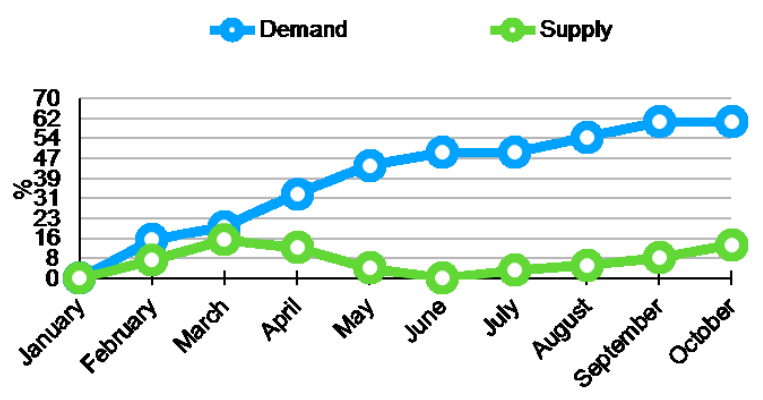

Figure 2 Dynamics of supply and demand for job provision [11]

This graph takes into account all areas of activity, but according to statistics provided by the same company, the hospitality sector has been seriously affected by the consequences of COVID-19 [11].

Another reason for the shortage of professional staff is the outdated approach and teaching methods in educational institutions involved in the training of personnel in the field of tourism: a lot of theory and little practice. The teaching methodology is divided into two types: traditional and modern methods [4]. The traditional method involves theory and repetition. Constant memorization of information, analysis and analytics of articles or another source in the Internet source, writing reports, abstracts, reports [4]. In comparison with traditional methods in modern teaching, the emphasis is on the interactive presentation of theoretical material, combining it with the practical part. One of the modern approaches in education is a competence-based approach, where the emphasis is on the practical part of the educational program. This approach is used by educational institutions that train personnel for the field of social and cultural services and tourism. In addition to training in educational institutions during the pandemic, a large number of online courses for training and professional retraining of personnel appeared. Online courses, distance learning of modules with embedded gamification: accumulating points, getting badges for passing a test or assignment, participating in conferences are also modern and popular types of studying educational material [4].

Online courses have become the most popular during the COVID-19 pandemic. Learning remotely means not wasting your free time on the road to the specified place of education. The second reason is that you can allocate time for training yourself. Thirdly, the duration of the courses: in a short time (2-3 months), you can go through several modules and receive a certificate of advanced training or professional retraining.

Despite the popularity of distance learning, offline

Table 2. Analysis of educational online programs in the direction of training in the field of social and cultural services and tourism [10], [12], [13]

\begin{tabular}{|l|l|}
\hline \multicolumn{1}{|c|}{ Professional retraining } & \multicolumn{1}{|c|}{ Professional development programs } \\
\hline Tourism and service management & Tourism and service \\
\hline $\begin{array}{l}\text { Innovative technologies for organizing the activities of } \\
\text { hotel and tourist complexes }\end{array}$ & Cultural heritage in the hospitality industry \\
\hline Tourism management & Tourism manager \\
\hline $\begin{array}{l}\text { Tour operator and travel agency activities in the field of } \\
\text { tourism }\end{array}$ & Investment support in the field of tourism \\
\hline Organization of excursion services & Innovative technologies in excursion practice \\
\hline Excursion & Mountaineering and mountaineering instructor-guide \\
\hline Tourism Economics & Guiding Instructor for Hiking and Trekking \\
\hline Legal regulation in tourism & Tourist destination branding \\
\hline Economics and Management of Tourism and Hospitality & $\begin{array}{l}\text { Classification of hotels and other accommodation facilities, } \\
\text { Classification of beaches }\end{array}$ \\
\hline Public administration in tourism & $\begin{array}{l}\text { Innovative technologies for organizing the activities of hotel } \\
\text { and tourist complexes }\end{array}$ \\
\hline
\end{tabular}


Table 3. Analysis of the example of educational programs in the direction of personnel training in the field of social and cultural services and tourism on the example of Russian State University of Tourism and Service [8]

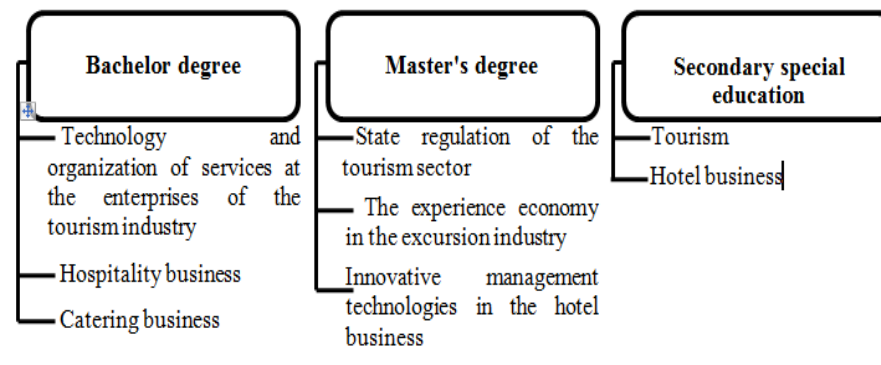

has its advantages. A huge advantage of offline learning is that the teacher adapts and changes the structure of the lesson and information for his students, adding or explaining information with his examples or ideas. Also, communication, communication within the group between the teacher and the student, as well as between students leads to the development of the necessary competencies.

In order to compare educational programs for special training, professional retraining and advanced training, implemented online and offline, Table 2 and Table 3 have been prepared. Table 1 shows the most common examples of online courses based on such Internet sources as "Ucheba.ru" [10], "TopTrending.ru" [12] and offered online courses at Lomonosov Moscow State University. [13]

Table 3 describes educational programs of different levels of training based on the educational base of the Russian State University of Tourism and Service.

Having analyzed the list of offered online courses and educational programs of higher educational institutions, we can come to the conclusion that the educational services market offers a wide range of training areas: from "Guided Tours" to "Management in the hospitality industry." However, the quality of program delivery will vary. Specialized universities undergo state accreditation of educational programs and are responsible for the quality of training in the field of tourism. Currently, within the framework of the implementation of educational programs, practitioners are involved, providing training in disciplines and modules that have a practice-oriented component. In order to ensure convenience in obtaining education, to ensure a continuous learning process in universities,

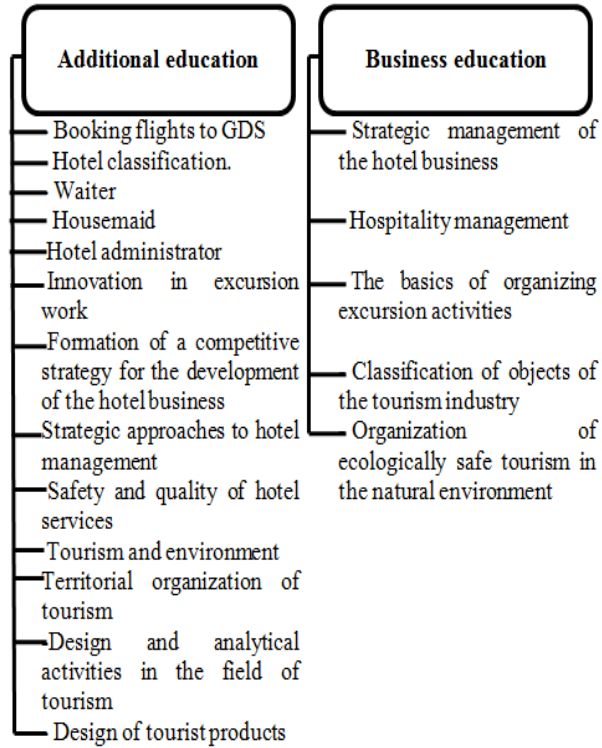

distance and mixed forms of education have also been introduced.

However, educational institutions will not be able to solve the problem of staff shortage and strengthen the positive image of the profession in the field of tourism on their own. This requires an integrated approach, including measures of state regulation and participation of entrepreneurial initiatives. The state, for its part, should pursue a systematic policy of supporting the tourism industry during the COVID-19 pandemic, employees working in this area. An important role in providing high-quality tourist services at enterprises in the service and tourism sector is played by the employer, who should be interested in motivated employees. Decent wages, career opportunities, work in a stable company, as well as the opportunity to study, gain new knowledge and skills within the framework of the work process can act as motivation. In order for an employee to perform his tasks on time and, most importantly, efficiently, he must be trained. To date, the method of mentoring is considered an effective tool for acquaintance with the standards of service at tourist service enterprises. The new employee is gradually immersed in work, given time to adapt and helped with various tasks. The experience of organizing the practice of students at an enterprise with future employment is successful. Within the framework of the organization of the practical block of educational programs, the interaction of the employer and the representative of the educational organization is carried out. In addition, the organization of internships at the enterprise allows the employer to select the most interested, prepared students and motivate them to work in their enterprise. 


\section{CONCLUSION}

The growth in demand for domestic tourism is due to the closure of borders during the COVID-19 pandemic. Whether the regions of the Russian Federation will be able to maintain the demand for tourism services from consumers after the opening of the borders will depend on many factors, one of which is the quality of service provision, which depends, among other things, on staffing the tourism sector.

Solving the issues of personnel shortage in tourism, training professional personnel, increasing the prestige of the profession and motivating employees should have a systematic approach. The synergy of measures of the Government of the Russian Federation to support the tourism industry, the flexibility of educational programs and their compliance with employers' requests, the participation of practitioners in the provision of the educational process, the introduction of mentoring methods at the enterprises of the tourism sector, the motivation and training of personnel, investment in the development of human capital are important tools for ensuring providing quality tourism services, maintaining the competitiveness of regional tourism services during the period of lifting restrictive measures and reducing tensions with the COVID-19 pandemic.

\section{REFERENCES}

[1] T.N. Ananyeva, The main directions of training for the tourism sector, in: Bulletin of the Association of universities of tourism and service, 3 (2012).

[2] M.V. Arifulin, L.S. Morozova, Strategy for the creation and development of transnational hotel chains: monograph (2012).

[3] V.Yu. Morozov, A.A. Popravkina, Features of training personnel in the field of tourism and hospitality in Russia: traditional and modern approaches, in: Service in Russia and abroad, 2 (58), (2015), p. 88-99.

[4] T.A. Shebzukhova, I.S. Klimenko, Modern approaches to personnel training for the tourism industry: a comparative analysis, in: Resorts. Service. Tourism, 1 (42), (2019), p. 40-43.

[5] Portal of Federal State Educational Standards of Higher Education. http://fgosvo.ru/fgosvo/152/150/25/116.

[6] Subsystem of scientific and educational support of the tourism industry. https://edu.russia.travel/secondary-vocationaleducation.html.

[7] M. Lomidze, ATOR: Realities of the Travel Market 2021/2022. https: //blog.travelpayouts.com/tpas2021ator/?Utm_sourc $\mathrm{e}=$ telegram\&utm_medium $=$ social\&utm_campaign =blogpost\&utm_content=tpas2021-ator_0311.
[8] Russian State University of Tourism and Service. Official site. Training programs. https://rguts.ru/programs/index.

[9] Federal Law of December 29, 2012 No. 273 (revised on December 8, 2020) "On education in the Russian Federation". https://legalacts.ru/doc/273_FZ-ob-obrazovanii/.

[10] Ucheba.ru: official site. https://www.ucheba.ru.

[11] HeadHunter: official site. https://kaliningrad.hh.ru.

[12] TopTrending.ru: official site. https://toptrending.ru.

[13] Lomonosov Moscow State University: official website. https://www.msu.ru. 